\title{
TECHNOLOGICAL-NUTRITIONAL QUALITY TRAITS AND RELATIONSHIP TO BIOACTIVE COMPOUNDS IN MESOAMERICAN AND ANDEAN BEANS ${ }^{1}$
}

\author{
NERINÉIA DALFOLLO RIBEIRO ${ }^{2 *}$, GREICE ROSANA KLÄSENER², HENRIQUE CALETTI MEZZOMO², \\ SKARLET DE MARCO STECKLING ${ }^{2}$
}

\begin{abstract}
The common bean exhibits wide genetic variability for technological quality traits, mineral concentrations, and bioactive compounds. For this reason, investigating the correlations between those traits in common bean lines of different gene pools contributes to the progress of biofortification programs. In the present study, two recombinant inbred line populations of Mesoamerican and Andean common bean were evaluated at the $\mathrm{F}_{5: 7}$ generation. Technological quality was evaluated based on mass of 100 grains and seed coat color, which was determined using a colorimeter that analyzed the $\mathrm{L}^{*}$ (white to black), $\mathrm{a}^{*}$ (green to red) and $\mathrm{b}^{*}$ (blue to yellow) values. The concentration of six minerals and bioactive compounds (phytates and phenolic compounds) was evaluated and used to characterize the nutritional composition of the lines. The evaluated common bean lines differed $(\mathrm{p} \leq 0.05)$ for all technological quality traits, mineral concentrations, and bioactive compounds, except for the zinc concentration in Andean beans. Seed coat color ( $\mathrm{L}^{*}, \mathrm{a}^{*}$, and $\mathrm{b}^{*}$ values) was highly correlated with most of the evaluated minerals and with the phytates in Mesoamerican beans. In Andean beans, seed coat color $\left(\mathrm{L}^{*}, \mathrm{a}^{*}\right.$, and $\mathrm{b}^{*}$ values) was correlated with the concentrations of potassium, magnesium, iron, and phenolic compounds. The nutritional composition of common bean lines of different classes is variable: black beans have higher concentrations of potassium, phosphorus, calcium, zinc, and phytates; carioca beans stand out with high magnesium concentration; and cranberry beans have higher concentrations of potassium, magnesium, and iron.
\end{abstract}

Keywords: Phaseolus vulgaris. Seed color. Minerals. Phytates. Phenolic compounds.

\section{CARACTERES DA QUALIDADE TECNOLÓGICA E NUTRICIONAL E RELAÇÃO COM COMPOSTOS BIOATIVOS EM FEIJÃO MESOAMERICANO E ANDINO}

\begin{abstract}
RESUMO - Os grãos de feijão apresentam grande variabilidade genética para os caracteres da qualidade tecnológica, concentração de minerais e compostos bioativos. Por isso, o estudo das correlações entre esses caracteres em linhagens de feijão de diferentes grupos gênicos proporciona avanços no programa de biofortificação. Para tanto, duas populações homozigotas recombinantes de feijão Mesoamericano e Andino foram avaliadas em geração $\mathrm{F}_{5: 7 .}$. A qualidade tecnológica foi analisada pela massa de 100 grãos e pela coloração dos grãos determinada em um colorímetro pelos valores de $\mathrm{L}^{*}$ (branco ao preto), a* (verde a vermelho) e b* (azul a amarelo). A concentração de seis minerais e de compostos bioativos (fitatos e compostos fenólicos) foi avaliada e usada para caracterizar a composição nutricional das linhagens. As linhagens de feijão avaliadas diferiram para todos os caracteres da qualidade tecnológica e para a concentração de minerais e de compostos bioativos, exceto para a concentração de zinco nas linhagens de feijão Andino. A coloração dos grãos (valores de $\mathrm{L}^{*}, \mathrm{a}^{*} \mathrm{e} \mathrm{b}^{*}$ ) apresentou alta correlação com a maioria dos minerais avaliados e com os fitatos em feijão Mesoamericano. Em feijão Andino, a coloração dos grãos (valores de $L^{*}, a^{*}$ e b*) foi correlacionada com as concentrações de potássio, magnésio, ferro e compostos fenólicos. A composição nutricional das linhagens de feijão de diferentes classes de grãos é variável: feijão preto apresenta as maiores concentrações de potássio, fósforo, cálcio, zinco e fitatos; feijão carioca se destaca pela alta concentração de magnésio; feijão rajado tem maior concentração de potássio, magnésio e ferro.
\end{abstract}

Palavras-chave: Phaseolus vulgaris. Coloração dos grãos. Minerais. Fitatos. Compostos fenólicos.

\footnotetext{
"Corresponding author

${ }^{1}$ Received for publication in 06/02/2020; accepted in 01/10/2021.

${ }^{2}$ Department of Plant Science, Universidade Federal de Santa Maria, Santa Maria, RS, Brazil; nerineia@hotmail.com - ORCID: 0000-0002 -5539-0160, rosanaklasener@hotmail.com - ORCID: 0000-0002-3957-0364, hc_mezzomo@hotmail.com - ORCID: 0000-0002-82209611, kati_ste@hotmail.com - ORCID: 0000-0003-3999-2089.
} 


\section{INTRODUCTION}

The common bean (Phaseolus vulgaris L.) is a component of the diet of many populations around the world. This food can be prepared in many ways and is found in a great variety of colors, sizes, and shapes, satisfying the most varied tastes.

In Brazil, the common bean cultivated area is 2,926,700 ha (CONAB, 2020) and per capita consumption is $17 \mathrm{~kg}$ inhabitant $^{-1}$ year $^{-1}$ (MAPA, 2018). The classes of common bean most widely produced and appreciated for consumption in Brazil are carioca (beige seed coat with brown streaks) and black. However, there has been a growing demand for gourmet beans, i.e., cranberry (cream seed coat with red streaks) and red mottled (red seed coat with cream streaks). Because these are used in the preparation of exquisite dishes in the domestic and international cuisine, they attain higher market value.

In view of this new market demand, commonbean breeding programs have endeavored to develop new cultivars of the cranberry and red mottled classes. To reach this goal, they have prioritized plant and grain traits that meet the demands of producers and the grain quality traits most appreciated by bean traders and consumers. Thus, technological quality has received greater attention by breeding programs. Mass of 100 grains and seed coat color are important visual traits that determine the acceptance of a new cultivar. Seed coat color can be assessed by a colorimeter, based on the $\mathrm{L}^{*}$ (luminosity, ranging from 0 [black] to 100 [white]), $\mathrm{a}^{*}$ (chromaticity $\mathrm{a}^{*}$; ranging from -60 [green] to +60 [red]), and $b^{*}$ (chromaticity $b^{*}$; ranging from -60 [blue] to +60 [yellow]) measurements. For the carioca and black bean classes, higher lightness (L* $\geq 55$ ) (ARNS et al., 2018) and lower lightness (L* $\leq$ 22) (RIBEIRO; POSSEBOM; STORCK, 2003), respectively, have been recommended in the selection of superior genotypes. Though recent studies have investigated the color of different classes of common bean (KAHRAMAN; ÖNDER, 2013; RIBEIRO et al., 2014a; GARCÍA-DÍAZ et al., 2018), no standards for the cranberry and red mottled classes have been proposed to meet the consumer preference.

The nutritional quality of common bean has been widely evaluated in genotypes cultivated in several countries, especially in terms of mineral concentrations. These studies have shown that mineral concentrations vary across genotypes in the same class of beans and across different classes, gene pools, and growing environments (AKOND et al., 2011; SILVA et al., 2012; GOUVEIA et al., 2014; STECKLING et al., 2017). However, biofortification in common bean has focused on increasing iron (JOST et al., 2013; RIBEIRO et al., 2013; MARTINS et al., 2016) and zinc (RIBEIRO et al., 2013; MARTINS et al., 2016; MAZIERO; RIBEIRO; FACCO, 2016) concentrations. The development of common bean cultivars with mineral -biofortified grains meets a worldwide demand for foods with high nutritional value. Nonetheless, the bioavailability of these minerals can be compromised by the presence of antinutritional factors such as phytates and phenolic compounds. For this reason, phytates and phenolic compounds were considered antinutrients for many decades. Contrastingly, several benefits to health have been associated with those bioactive compounds (SCHLEMMER et al., 2009; MOJICA et al., 2015).

Nevertheless, the literature lacks information on the relationship between technological and nutritional quality traits and the bioactive compounds present in common beans. No studies have been found determining whether these correlations differ in beans of different gene pools. If this is confirmed, the nutritional composition of different classes of common bean may vary. On these bases, this study proposes to determine whether two recombinant inbred line populations of Mesoamerican and Andean common bean exhibit differences in their technological quality traits, mineral concentrations, and bioactive compounds; investigate the correlations between those traits in two populations; and determine whether lines of different common bean classes vary in nutritional composition.

\section{MATERIAL AND METHODS}

The experiments were conducted in the experimental area of the Common-Bean Breeding Program of the Federal University of Santa Maria, in Santa Maria, Rio Grande do Sul (RS), Brazil, on a typic alitic Argisol, Hapludalf. The municipality of Santa Maria is located in the Central Depression region of RS State, at the following geographic coordinates: $29^{\circ} 42^{\prime}$ south latitude, $53^{\circ} 43^{\prime}$ longitude west of Greenwich, and at $95 \mathrm{~m}$ above the sea level. The climate of the region is a humid subtropical type with hot summers and no clearly defined dry season.

The first experiment was implemented as a 2017 rainy season crop (temperature range from 10 to $37{ }^{\circ} \mathrm{C}$ and rainfall from 0 to $45 \mathrm{~mm}$ ) to evaluate the Mesoamerican common bean lines, obtained from the cross between cultivars BRS Esteio and SCS 205 Riqueza (Figure 1). These cultivars were previously selected by Ribeiro et al. (2013) due to differences observed in the concentrations of potassium, calcium, iron, and zinc in the grains. An $11 \times 11$ simple lattice design was adopted in which 121 common bean genotypes were evaluated, consisting of 100 lines in the $\mathrm{F}_{5: 7}$ generation, two parental cultivars, and 19 common bean cultivars (controls). This experiment was composed of carioca and black beans, which are the most widely produced and consumed common bean classes in Brazil. 


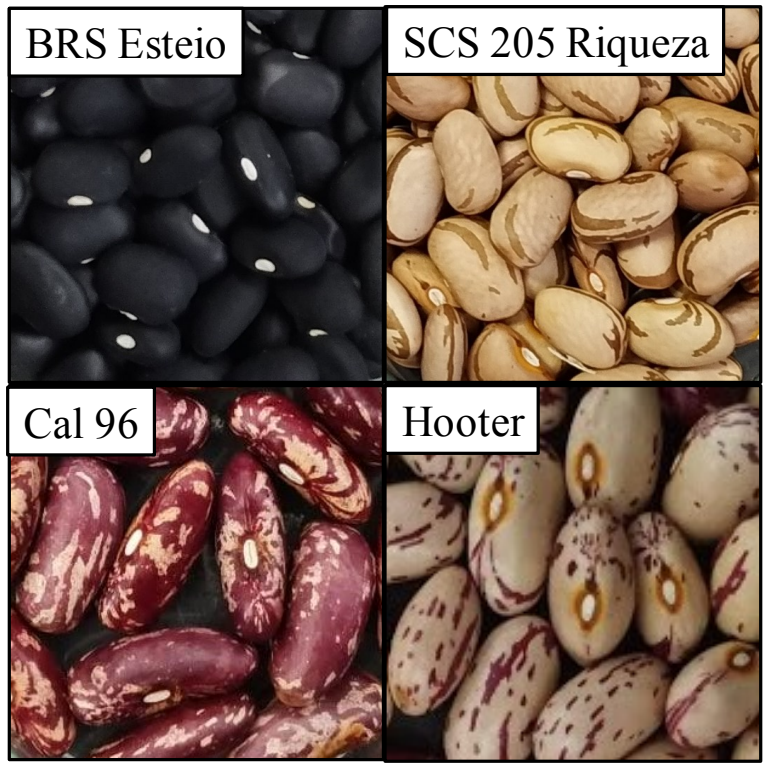

Figure 1. Image of the four parents used in the crosses representing the black (BRS Esteio), carioca (SCS 205 Riqueza), red mottled (Cal 96), and cranberry (Hooter) bean classes evaluated.

The second experiment was sown as a 2018 dry season crop (temperature range from 2 to $36{ }^{\circ} \mathrm{C}$ and rainfall from 0 to $100 \mathrm{~mm}$ ) to evaluate the Andean common bean lines derived from the Hooter $\times$ Cal 96 cross (Figure 1). Those cultivars were contrasting for the concentrations of potassium, calcium, iron, and zinc (RIBEIRO et al., 2014b). An $8 \times 8$ simple lattice design was used to evaluate 64 common bean genotypes, represented by $52 \mathrm{~F}_{5: 7}$ lines, two parental cultivars (Hooter and Cal 96), and 10 cultivars (controls). In this experiment, the genotypes have standard Hooter (cranberry) and Cal 96 grains (red mottled). The cranberry and red mottled bean classes are produced on a smaller scale in Brazil. However, because of their greater market value, the cultivation of these bean classes contributes to increasing the revenue of producers, in addition to being highly demanded for exports to European and African countries.

In both experiments, the experimental plot consisted of one $1 \mathrm{~m}$ row spaced $0.50 \mathrm{~m}$ apart. Sowing density was 15 seeds per linear meter. The soil showed the following chemical composition before the establishment of the experiments: organic matter - $1.80 \%$; base saturation - 73.90\%; $\mathrm{pH}\left(\mathrm{H}_{2} 0\right)$ 6.10; effective cation exchange capacity -9.90 cmolc $\mathrm{dm}^{-3}$; potassium - $80.00 \mathrm{mg} \mathrm{dm}{ }^{-3}$; phosphorus -12.70 mg dm${ }^{-3}$; calcium: $-6.70 \mathrm{cmolc} \mathrm{dm}^{-3}$; iron - 2.026.50 $\mathrm{mg} \mathrm{dm}{ }^{-3}$; copper $-1.20 \mathrm{mg} \mathrm{dm}^{-3}$; and zinc $-0.50 \mathrm{mg}$ $\mathrm{dm}^{-3}$. Fertilization was performed with $275 \mathrm{~kg} \mathrm{ha}^{-1}$ of the $\mathrm{N}-\mathrm{P}_{2} \mathrm{O}_{5}-\mathrm{K}_{2} \mathrm{O} \quad 5-20-20$ formula (urea - $45 \%$ nitrogen; triple superphosphate - $18 \% \mathrm{P}_{2} \mathrm{O}_{5}$; and potassium chloride $-60 \% \mathrm{~K}_{2} \mathrm{O}$ ) at furrow sowing and $67 \mathrm{~kg} \mathrm{ha}^{-1}$ of urea ( $45 \%$ nitrogen) were distributed in the growth stage of the first trifoliate leaf. No micronutrients were added to the fertilizers. Uniform management practices were applied in both experiments and followed the technical recommendations for the common bean crop in the RS State, Brazil (CTSBF, 2012).

Plants were harvested and grains were processed at maturity (R9 stage). Both steps were performed manually to prevent mechanical damage and to prevent the samples from being contaminated by metals. The grains were sun-dried, and, when needed, oven-dried at $40{ }^{\circ} \mathrm{C}$ until reaching $13 \%$ moisture. The grains were stored under refrigeration (temperature of $5{ }^{\circ} \mathrm{C}$ and relative humidity of $75 \%$ ) for a month before the assessment period.

Mass of 100 grains was determined in triplicate for each experimental plot. Seed coat color $\left(\mathrm{L}^{*}, \mathrm{a}^{*}\right.$, and $\mathrm{b}^{*}$ values) was determined using a portable colorimeter (CR 410, Konica Minolta, Osaka, Japan). The grain samples were placed in a petri dish $(6.0 \mathrm{~cm}$ diameter $\times 1.5 \mathrm{~cm}$ height $)$. The equipment was previously calibrated with a standard white ceramic plate. The equipment sensor was placed under the grains and three readings were taken for each sample. The $\mathrm{L}^{*}$ value characterized luminosity, ranging from black (0) to white (100); the $a^{*}$ value represented chromaticity $a^{*}$, which measures the variation from green-bluish (negative values) to red-purple shades (positive values); lastly, the $b^{*}$ value indicates chromaticity $b^{*}$, which quantifies the variation from blue (negative values) to yellow (positive values).

Raw grain samples with $13 \%$ moisture were ground in a knife micro-mill (Q298A21, Quimis, São Paulo, Brazil) until a flour with uniform particle size was obtained. Aliquots of $0.5 \mathrm{~g}$ from the samples of raw bean flour were used for the digestion process with a nitric and perchloric acid solution $\left(\mathrm{HNO}_{3}+\right.$ $\mathrm{HClO}_{4}$, at a 3:1 ratio by volume). The potassium concentration was read using a flame photometer 
(B262, Micronal, São Paulo, Brazil), while the phosphorus concentration was measured using an optical emission spectrophotometer (AA-7000, Shimadzu, São Paulo, Brazil). The concentrations of calcium, magnesium, iron, and zinc were determined using an atomic absorption spectrophotometer (AAS, Perkin Elmer AAnalyst 200, Waltham, United States).

The phytates were quantified in 2.0-g aliquots of bean flour with the addition of $40 \mathrm{~mL}$ of $2.4 \%$ hydrochloric acid $(\mathrm{HCl})$, following the methodology proposed by Latta and Eskin (1980). The phytate concentration was measured using an UV/visible spectrophotometer in the 500-nm band (SP-220, Bioespectro, São Paulo, Brazil). Phenolic compounds were determined in 0.2-g samples of bean flour by the extraction method described by Singleton and Rossi Júnior (1965). The phenolic compounds were read by an UV-vis and microplate fluorescence reader (AF2200, Eppendorf, Hamburg, Germany), at $765 \mathrm{~nm}$. A standard curve with gallic acid was prepared and results were expressed as $\mathrm{mg}$ of gallic acid equivalent per $\mathrm{g}$ of dry matter $(\mathrm{mg}$ GAE $\mathrm{g}^{-1} \mathrm{DM}$ ).

The obtained data were subjected to analysis of variance, and the efficiency of the lattice design in relation to the randomized block design was evaluated as described by Ramalho, Ferreira and Oliveira (2000). Pearson's linear correlation coefficient was estimated from the phenotypic correlation matrix for all pairs of traits for which a significant difference was observed for the "genotype" source of variation, for each experiment. Student's $t$ test was used to evaluate the significance of the correlation coefficients, at the $5 \%$ probability level. Statistical analyses were performed using Genes software (CRUZ, 2016).

\section{RESULTS AND DISCUSSION}

\section{Overall results}

Significant differences $(\mathrm{p} \leq 0.05)$ were observed for all traits evaluated in the Mesoamerican common bean lines, indicating the existence of genetic variability for the technological quality traits and for the mineral and phytate concentrations. Similarly, previous works showed that Mesoamerican common bean genotypes differed for mass of 100 grains (STECKLING et al., 2017), seed coat color determined by the colorimeter (MOJICA et al., 2015), mineral concentration (McCLEAN et al., 2017; STECKLING et al., 2017), and phytate concentration (OOMAH; BLANCHARD; BALASUBRAMANIAN, 2008; BLAIR et al., 2012). The existence of genetic variability is an indispensable condition for the development of biofortified cultivars and with bioactive compounds that meet the grain size and color standards most appreciated in carioca and black beans.

The treatment effect was significant for all traits evaluated in the Andean common bean lines, except for the zinc concentration. Preliminary studies also revealed wide genetic variations for mass of 100 grains (RIBEIRO et al., 2014a), seed coat color measured by the colorimeter (RIBEIRO et al., 2014a), mineral concentration (GOUVEIA et al., 2014; KATUURAMU et al., 2018), and phenolic compound concentration (GARCÍA-DÍAZ et al., 2018) in Andean common bean genotypes. The current results indicate it is possible to develop Andean common bean cultivars with biofortified grains and with bioactive compounds that meet the standards of higher acceptance in the international market for cranberry (very light) and red mottled (dark red) beans.

The efficiency of the lattice design compared to the randomized block design was higher than $100 \%$ for most of the traits evaluated in both experiments. In this case, the use of the lattice design is justified, as recommended by Ramalho, Ferreira and Oliveira (2000). Coefficients of variation $(\mathrm{CV}) \leq$ $20 \%$ were obtained for the traits evaluated in both experiments, except for bioactive compounds, phytates $(\mathrm{CV}=23.50 \%)$, and phenolic compounds $(\mathrm{CV}=21.09 \%)$. Zilio, Souza and Coelho (2017) observed $\mathrm{CV} \leq 29.80 \%$ for the mineral and phytate concentrations evaluated in 26 common bean genotypes of the Mesoamerican and Andean gene pools. These results suggest that adjustments in the technique for the extraction of bioactive compounds in common bean can contribute to increasing experimental precision.

\section{Correlations between technological quality traits,} minerals, and phytates in Mesoamerican beans

Mass of 100 grains was not correlated with any of the traits evaluated in the Mesoamerican beans (Table 1). Similarly, Steckling et al. (2017) found no correlations between mass of 100 grains and six minerals evaluated in 14 carioca and black common bean lines. However, Campion et al. (2013) found a negative correlation of intermediate magnitude between mass of 100 grains and the concentrations of phosphorus, iron, and zinc in nine common bean lines of white, brown and black grains grown in Italy. In the present study, we evaluated common bean lines of the carioca and black classes, whose mass of 100 grains is between 25 and $30 \mathrm{~g}$. This small amplitude of variation may explain the lack of significant correlations between mass of 100 grains and the other evaluated traits. 
N. D. RIBEIRO et al.

Table 1. Pearson's correlation estimates between mass of 100 grains (M100G), luminosity (L), chromaticity a* (a), chromaticity $b^{*}(\mathrm{~b})$, and concentrations of potassium $(\mathrm{K})$, phosphorus $(\mathrm{P})$, calcium $(\mathrm{Ca})$, magnesium $(\mathrm{Mg})$, iron $(\mathrm{Fe})$, zinc $(\mathrm{Zn})$, and phytate (Phy) obtained in Mesoamerican common bean lines.

\begin{tabular}{|c|c|c|c|c|c|c|c|c|c|c|}
\hline & $\mathrm{L}$ & $\mathrm{a}$ & $\mathrm{b}$ & K & $\mathrm{P}$ & $\mathrm{Ca}$ & $\mathrm{Mg}$ & $\mathrm{Fe}$ & $\mathrm{Zn}$ & Phy \\
\hline M100G & 0.433 & 0.422 & 0.424 & -0.528 & -0.577 & -0.462 & 0.305 & -0.496 & -0.455 & -0.461 \\
\hline L & & $0.998^{*}$ & $0.999^{*}$ & $-0.822^{*}$ & $-0.879^{*}$ & $-0.971^{*}$ & $0.977^{*}$ & -0.420 & $-0.746^{*}$ & $-0.949^{*}$ \\
\hline $\mathrm{a}$ & & & $1.000^{*}$ & $-0.829^{*}$ & $-0.879^{*}$ & $-0.974^{*}$ & $0.971^{*}$ & -0.420 & $-0.751^{*}$ & $-0.951^{*}$ \\
\hline$b$ & & & & $-0.827^{*}$ & $-0.878^{*}$ & $-0.974^{*}$ & $0.972^{*}$ & -0.421 & $-0.749^{*}$ & $-0.951^{*}$ \\
\hline K & & & & & $0.985^{*}$ & $0.926^{*}$ & $-0.704^{*}$ & $0.820^{*}$ & $0.974^{*}$ & $0.879^{*}$ \\
\hline $\mathrm{P}$ & & & & & & $0.956^{*}$ & $-0.775^{*}$ & $0.783^{*}$ & $0.956^{*}$ & $0.921^{*}$ \\
\hline $\mathrm{Ca}$ & & & & & & & $-0.909^{*}$ & $0.610^{*}$ & $0.866^{*}$ & $0.962^{*}$ \\
\hline $\mathrm{Mg}$ & & & & & & & & -0.263 & $-0.620^{*}$ & $-0.892^{*}$ \\
\hline $\mathrm{Fe}$ & & & & & & & & & $0.837^{*}$ & 0.555 \\
\hline $\mathrm{Zn}$ & & & & & & & & & & 0.832 \\
\hline
\end{tabular}

*Significant by the Student's t-test at 0.05 probability.

The $L^{*}, a^{*}$, and $b^{*}$ values were positively correlated $(r \geq 0.998)$, showing that luminosity (variation in color from black to white), chromaticity $\mathrm{a}^{*}$ (variation in shade from green to red), and chromaticity $b^{*}$ (variation in shade from blue to yellow) were highly correlated in the carioca and black beans. Because correlated pairs of traits exhibit similar information, the use of both traits is not recommended in the selection process. In this case, selection based on higher lightness $\left(\mathrm{L}^{*} \geq 55\right)$ was recommended for carioca beans (ARNS et al., 2018) and lower lightness $\left(\mathrm{L}^{*} \leq 22\right)$ was indicated for black beans (RIBEIRO; POSSEBOM; STORCK, 2003) in the development of common bean cultivars with a grain color that meets consumers' demand for those grain classes.

The $L^{*}, a^{*}$, and $b^{*}$ values showed a high negative correlation with the concentrations of potassium, phosphorus, calcium, zinc, and phytates ( $\mathrm{r} \geq-0.746)$ but were positively and highly correlated $(r \geq 0.971)$ with the magnesium concentration. These results suggest that the black common bean lines (lower $\mathrm{L}^{*}, \mathrm{a}^{*}$, and $\mathrm{b}^{*}$ values) have higher concentrations of potassium, phosphorus, calcium, zinc, and phytates. The carioca common bean lines (higher $\mathrm{L}^{*}, \mathrm{a}^{*}$, and $\mathrm{b}^{*}$ values), in turn, have a higher magnesium concentration than the black common bean lines, which agrees with the findings reported by Silva et al. (2012) in an evaluation of 100 common bean lines of different classes. On the other hand, Kahraman and Önder (2013) did not observe significant correlations between the $L^{*}, a^{*}$, and $b^{*}$ values and the concentrations of 10 minerals evaluated in 39 bean genotypes cultivated in Turkey. These results indicate that bean lines of different classes may show differences in nutritional composition. From the tested Mesoamerican common bean lines, the black beans can be indirectly selected based on higher concentrations of potassium, phosphorus, calcium, zinc, and phytates. The carioca common bean lines, in turn, can be indirectly selected based on higher magnesium concentration.

Positive correlation estimates of predominantly high magnitude were obtained for most of the evaluated mineral pairs: potassium was correlated with phosphorus, calcium, iron, and zinc; phosphorus was correlated with calcium, iron, and zinc; calcium was correlated with iron and zinc; and iron was correlated with zinc. A similar response was observed when researchers evaluated the correlation between 10 minerals in bean genotypes cultivated in Turkey (KAHRAMAN; ÖNDER, 2013). However, most correlation estimates between minerals were of low or intermediate magnitude in experiments exclusively with Mesoamerican common bean genotypes (STECKLING et al., 2017) and with Mesoamerican and Andean common bean genotypes (SILVA et al., 2012). The hypothesis is that the genetic diversity of the evaluated germplasm, the soil factors, and the meteorological conditions of the growing environment explain the different responses observed in the literature. For this reason, more in-depth knowledge is necessary about the association between the traits that confer nutritional quality to common bean lines in a biofortification program.

Magnesium, in turn, showed a high negative correlation with potassium, phosphorus, and calcium, but an intermediate correlation with zinc. This response has practical implications to the biofortification of common bean, since increasing the potassium concentration in the grains leads to an increase in the concentrations of phosphorus, 
calcium, and zinc and a simultaneous decrease in magnesium concentration. In this case, complementary studies are required to determine whether biofortification for several minerals in common bean may compromise magnesium nutrition.

The phytates were inversely correlated with the magnesium concentration, showing that increasing phytate concentration resulted in decreasing magnesium concentration in Mesoamerican common bean lines. However, the phytates were directly correlated $(r \geq 0.832)$ with the concentrations of potassium, phosphorus, calcium, and zinc. Oomah, Blanchard and Balasubramanian (2008) noted that the phytate concentration had an intermediate positive correlation with the concentrations of phosphorus, calcium, and magnesium, but found no correlations between phytates-iron and phytates-zinc in 10 common bean cultivars of the Mesoamerican and Andean gene pools. By contrast, Blair et al. (2012) found a low correlation between phytate and phosphorus concentrations in common bean populations obtained from a cross between parents of the Mesoamerican and Andean gene pools. Akond et al. (2011) also observed low-magnitude correlation estimates between the phytate concentration and concentrations of calcium, magnesium, iron, and zinc in 29 common bean genotypes of Mesoamerican and Andean gene pools. These findings suggest that the correlation between phytates and the minerals may vary across different grain classes, warranting further investigation by breeding programs. In the present study, indirect selection using phytate concentration was highly efficient to increase the concentrations of potassium, phosphorus, calcium, and zinc in Mesoamerican common bean lines.

Variations in nutritional composition were detected between the evaluated Mesoamerican common bean lines. The black common bean lines showed the highest concentrations of potassium, phosphorus, calcium, zinc, and phytates, whereas the carioca common bean lines stood out with high magnesium concentrations. These lines may be used in diets to improve the nutrition and health of consumers. For this, the absorption, bioavailability, and retention of these nutrients must be assessed in the black and carioca bean lines.

\section{Correlations between technological quality traits, minerals, and phenolic compounds in Andean beans}

Mass of 100 grains was positively correlated with the phosphorus concentration $(r=0.669)$ and negatively correlated with the concentrations of calcium, magnesium, and phenolic compounds $(\mathrm{r} \geq-0.725)$ (Table 2). No previous studies have been found in the literature investigating the correlation between mass of 100 grains and the macromineral concentration in Andean common bean lines. Campion et al. (2013) found no significant correlations between mass of 100 grains and the phenolic compound concentration, but reported that mass of 100 grains was negatively correlated with the iron and zinc concentrations in nine bean lines with different grain colors assessed in Italy. The genetic diversity of the evaluated lines and the different growing countries explain the different responses observed for the correlation estimates. Nevertheless, in the present study, we found that cranberry and red mottled bean lines with higher mass of 100 grains have higher phosphorus concentration and lower concentrations of calcium, magnesium, and phenolic compounds. Therefore, increasing mass of 100 grains may reduce the nutritional value of these classes of common bean.

Table 2. Pearson's correlation estimates between mass of 100 grains (M100G), luminosity (L), chromaticity a* (a), chromaticity $b^{*}(\mathrm{~b})$, and concentrations of potassium $(\mathrm{K})$, phosphorus $(\mathrm{P})$, calcium $(\mathrm{Ca})$, magnesium $(\mathrm{Mg})$, iron $(\mathrm{Fe})$, and phenolic compounds (Pc) obtained in Andean common bean lines.

\begin{tabular}{|c|c|c|c|c|c|c|c|c|c|}
\hline & $\mathrm{L}$ & $\mathrm{a}$ & $\mathrm{b}$ & $\mathrm{K}$ & $\mathrm{P}$ & $\mathrm{Ca}$ & $\mathrm{Mg}$ & $\mathrm{Fe}$ & $\mathrm{Pc}$ \\
\hline M100G & -0.400 & 0.496 & -0.326 & -0.066 & $0.669^{*}$ & $-0.725^{*}$ & $-0.891^{*}$ & -0.057 & $-0.970^{*}$ \\
\hline $\mathrm{L}$ & & $-0.994^{*}$ & $0.995^{*}$ & $0.839^{*}$ & 0.198 & -0.269 & $0.763^{*}$ & $0.617^{*}$ & 0.579 \\
\hline $\mathrm{a}$ & & & $-0.980^{*}$ & $-0.804^{*}$ & -0.102 & 0.166 & $-0.828^{*}$ & -0.587 & $-0.664^{*}$ \\
\hline $\mathrm{b}$ & & & & $0.851^{*}$ & 0.283 & -0.342 & $0.709^{*}$ & $0.632^{*}$ & 0.514 \\
\hline K & & & & & 0.272 & -0.369 & 0.486 & 0.269 & 0.281 \\
\hline $\mathrm{P}$ & & & & & & $-0.883^{*}$ & -0.378 & 0.445 & -0.562 \\
\hline $\mathrm{Ca}$ & & & & & & & 0.403 & -0.586 & $0.608^{*}$ \\
\hline $\mathrm{Mg}$ & & & & & & & & 0.273 & $0.966^{*}$ \\
\hline $\mathrm{Fe}$ & & & & & & & & & 0.119 \\
\hline
\end{tabular}

*Significant by the Student's t-test at 0.05 probability. 
High correlation estimates were detected between $\mathrm{L}^{*}$ and $\mathrm{a}^{*}(\mathrm{r}=-0.994)$ and $\mathrm{L}^{*}$ and $\mathrm{b}^{*}$ $(\mathrm{r}=0.995)$, indicating that higher lightness (higher $\mathrm{L}^{*}$ value) in the seed coat color results in slightly redder (lower $\mathrm{a}^{*}$ value) and yellower (higher $\mathrm{b}^{*}$ value) shades in the secondary color in cranberry beans. The red mottled beans, in turn, exhibited lower lightness (lower $\mathrm{L}^{*}$ value) in the seed coat color and a redder (higher $\mathrm{a}^{*}$ value) and slightly yellow (lower $b^{*}$ value) secondary color. The $a^{*}$ and $b^{*}$ values were inversely correlated $(r=-0.980)$, which shows the diversity of red and yellow color patterns in beans of the evaluated classes. Similarly, Kahraman and Önder (2013) observed a high negative correlation between the $\mathrm{L}^{*}$ and $\mathrm{a}^{*}$ values, but the magnitude and sign of the correlations found between $L^{*}$ and $b^{*}$ and between $a^{*}$ and $b^{*}$ were different from those found in the present study. Those authors evaluated 39 common bean genotypes grown in Turkey, but did not describe the grain class or gene pool of the evaluated accessions. These results indicate that the color pattern $\left(\mathrm{L}^{*}, \mathrm{a}^{*}\right.$, and $\left.\mathrm{b}^{*}\right)$ should be studied in greater depth in different classes of common bean, considering that the observed correlations between the $\mathrm{L}^{*}, \mathrm{a}^{*}$, and $\mathrm{b}^{*}$ values differed between Mesoamerican (carioca and black classes) and Andean (cranberry and red mottled classes) gene pools.

The $L^{*}$ and $b^{*}$ values showed a positive correlation of intermediate to high magnitude ( $r \geq 0.617$ ) with the concentrations of potassium, magnesium, and iron, demonstrating that the cranberry common bean lines (higher $\mathrm{L}^{*}$ and $\mathrm{b}^{*}$ values) have higher concentrations of those minerals. The $\mathrm{a}^{*}$ value, in turn, was negatively correlated ( $r \geq-0.664)$ with the concentrations of potassium, magnesium, and phenolic compounds. Thus, the red mottled common bean lines (higher a* values) have lower concentrations of potassium, magnesium, and phenolic compounds when compared to the cranberry common bean lines. Kahraman and Önder (2013), on the other hand, observed no significant correlations between seed coat color $\left(\mathrm{L}^{*}, \mathrm{a}^{*}\right.$, and $\mathrm{b}^{*}$ values) and the concentration of 10 minerals evaluated in common bean genotypes cultivated in Turkey. Those results suggest that the correlation between seed coat color and concentrations of minerals and bioactive compounds varies across genotypes of different gene pools, as observed in the present study, and may vary across common bean genotypes of different classes. From the tested Andean common bean lines, the cranberry beans can be indirectly selected based on higher concentrations of potassium, magnesium, and iron.

Among the evaluated pairs of minerals, a high negative correlation was observed only between phosphorus and calcium $(\mathrm{r}=-0.883)$, suggesting that an increase in the concentration of one of these minerals resulted in a decrease in the other. However, Katuuramu et al. (2018) found no correlations between phosphorus and calcium in 206 genotypes of Andean beans in an experiment investigating the concentration of those minerals in cooked grains. No significant correlation was detected for any of the other pairs of minerals analyzed in the present study, indicating that these minerals are inherited independently in Andean beans. Nevertheless, a positive correlation of low to intermediate magnitude was found between various minerals evaluated in 59 genotypes of Andean beans cultivated on Madeira Island (GOUVEIA et al., 2014) and in 206 genotypes of Andean beans cultivated in the United States (KATUURAMU et al., 2018). In the current study, the lack of correlations between most of the minerals evaluated in Andean beans shows that there are no linked genes or pleiotropic effects. In this situation, selecting superior genotypes is expected to be an easy task, since the genetic values of the traits are independent (BALESTRE et al., 2013).

Phenolic compounds were positively correlated with the concentrations of calcium $(\mathrm{r}=0.608)$ and magnesium $(\mathrm{r}=0.966)$. Conversely, Oomah, Blanchard and Balasubramanian (2008) found no significant correlations between phenolic compounds and calcium and magnesium concentrations in 10 common bean cultivars of different classes cultivated in Canada. In the cranberry and red mottled lines evaluated here, the increasing phenolic compound concentration led to increases in the calcium and magnesium concentrations in the grains. Just as calcium and magnesium (MORAGHAN; GRAFTON, 2002), phenolic compounds (GARCÍA-DÍAZ et al., 2018) are concentrated mostly in the seed coat of the common bean, which has practical implications to cooking. Pinto bean genotypes, which showed a high phenolic compound concentration, were rapidly cooked (PIRHAYATI; SOLTANIZADEH; KADIVAR, 2011). Moreover, Wu, James and Anderson (2005) found that the calcium and magnesium concentrations were negatively correlated with rupture in dark red kidney beans during thermal processing. In other words, increasing the calcium and magnesium concentrations in the grains reduced their rupture during cooking. The maintenance of grain integrity during cooking is an important characteristic for domestic cooking and for the canning industry, since consumers prefer whole grains; i.e., grains that do not rupture during cooking. In the present study, indirect selection using phenolic compound concentration showed intermediate efficiency to increase calcium concentration and high efficiency to increase magnesium concentration in Andean common bean lines. Therefore, increasing the concentrations of phenolic compounds, calcium, and magnesium in Andean beans is not expected to result in a longer cooking time, which would restrict the acceptance of those lines.

In the present study, beans of different classes 
exhibited variations in nutritional composition. The black common bean lines showed higher concentrations of potassium, phosphorus, calcium, zinc, and phytates, whereas the carioca common bean lines had a higher magnesium concentration. The cranberry lines, in turn, have higher concentrations of potassium, magnesium, and iron. Therefore, varying the bean class/color in the diet can contribute to better nutrition and provide several health benefits which can be found in different classes of common bean. This is because some of the functions of potassium are to reduce blood pressure and the risks of developing diabetes (EKMEKCIOGLU et al., 2016). Phosphorus and calcium contribute to the maintenance of bones and teeth (PRAVST, 2011; WIMALAWANSA; RAZZAQUE; AL-DAGHRI, 2018). Magnesium acts in the prevention of diabetes, osteoporosis and cardiovascular disease (ALAWI; MAJONI; FALHAMMAR, 2018). Zinc helps to control dermatitis (GIBSON, 2012) and iron is important in preventing anemia (CAMASCHELLA, 2015). Phytates perform similar anticancer (lung, liver, breast, prostate, and skin), antioxidant, and anticalcification activities (SCHLEMMER et al., 2009). The phenolic compounds present in common bean are a good natural source of antioxidants and $\alpha$ amylase and $\alpha$-glucosidase enzyme inhibitors that degrade starch, which makes them important for the treatment of type-2 diabetes (MOJICA et al., 2015). For this reason, further in-depth knowledge is necessary about the absorption, bioavailability, and retention of these minerals for the common bean biofortification program.

\section{CONCLUSIONS}

The Mesoamerican common bean lines differ in technological quality traits and in their concentrations of minerals and phytates. The Andean common bean lines, in turn, show genetic variability for technological quality traits, phenolic compounds, and mineral concentration, except zinc.

Seed coat color $\left(\mathrm{L}^{*}, \mathrm{a}^{*}\right.$, and $\mathrm{b}^{*}$ values) is highly correlated with most of the evaluated minerals and with phytates in Mesoamerican beans. In Andean beans, seed coat color (L*, a*, and $\mathrm{b}^{*}$ values) is correlated with the concentrations of potassium, magnesium, iron, and phenolic compounds.

The black common bean lines present the highest concentrations of potassium, phosphorus, calcium, zinc, and phytates, whereas the carioca common bean lines stood out with a high magnesium concentration. The cranberry common bean lines show higher concentrations of potassium, magnesium, and iron.

\section{ACKNOWLEDGEMENTS}

To the National Council for Scientific and Technological Development (CNPq) for the financial support and scholarships. To the Coordination for the Improvement of Higher Education Personnel (CAPES) for the grants awarded.

\section{REFERENCES}

AKOND, A. S. M. G. M. et al. Minerals (Zn, Fe, Ca and $\mathrm{Mg}$ ) and antinutrient (phytic acid) constituent in common bean. American Journal of Food Technology, 6: 235-243, 2011.

ALAWI, A. M. AL.; MAJONI, S. W.; FALHAMMAR, H. Magnesium and human health: perspectives and research directions. International Journal of Endocrinology, 2018: 1-17, 2018.

ARNS, F. D. et al. Combined selection in carioca beans for grain size, slow darkening and fast-cooking after storage times. Euphytica, 214: 1-12, 2018.

BALESTRE, M. et al. Applications of multi-trait selection in common bean using real and simulated experiments. Euphytica, 189: 225-238, 2013.

BLAIR, M. W. et al. Inheritance of seed phytate and phosphorus levels in common bean (Phaseolus vulgaris L.) and association with newly-mapped candidate genes. Molecular Breeding, 30: 12651277, 2012.

CAMASCHELLA, C. Iron-deficiency anemia. The New England Journal of Medicine, 372: 18321843, 2015.

CAMPION, B. et al. Genetic reduction of antinutrients in common bean (Phaseolus vulgaris L.) seed, increases nutrients and in vitro iron bioavailability without depressing main agronomic traits. Field Crops Research, 141: 27-37, 2013.

CTSBF - Comissão Técnica Sul Brasileira de Feijão. Informações técnicas para o cultivo de feijão na Região Sul brasileira 2012. 2. ed. Florianópolis, SC: EPAGRI, 2012. 157 p.

CONAB - Companhia Nacional de Abastecimento. Série Histórica das safras: feijão total $\left(1^{\mathrm{a}}, 2^{\mathrm{a}}\right.$ e $3^{\mathrm{a}}$ safras). Safra 2019/2020. Brasília-DF, 2020. Disponível em: < https://www.conab.gov.br/infoagro/safras/serie-historica-das-safras? start $=20>$.

Acesso em: 04 jan. 2021.

CRUZ, C. D. Genes Software - Extended and 
integrated with the R, Matlab and Selegen. Acta Scientiarum. Agronomy, 38: 547-552, 2016.

EKMEKCIOGLU, C. et al. The role of dietary potassium in hypertension and diabetes. Journal Physiology and Biochemistry, 72: 93-106, 2016.

GARCÍA-DÍAZ, Y. D. et al. Bioactive compounds and antioxidant activity in the common bean are influenced by cropping season and genotype. Chilean Journal of Agricultural Research, 78: 255 $-265,2018$.

GIBSON, R. S. Zinc deficiency and human health: etiology, health consequences, and future solutions. Plant and Soil, 361: 291-299, 2012.

GOUVEIA, C. S. S. et al. Nutritional and mineral variability in 52 acessions of common bean varieties (Phaseolus vulgaris L.) from Madeira Island. Agricultural Sciences, 5: 317-329, 2014.

JOST, E. et al. Comparison among direct, indirect and index selections on agronomic traits and nutritional quality traits in common bean. Journal of the Science of Food and Agriculture, 93:10971104, 2013.

KAHRAMAN, A.; ÖNDER, M. Correlations between seed color and nutritional composition of dry bean. Ratarstvo i Povrtarstvo, 50: 8-13, 2013.

KATUURAMU, D. N. et al. Genome-wide association analysis of nutritional compositionrelated traits and iron bioavailability in cooked dry beans (Phaseolus vulgaris L.). Molecular Breeding, 38: 1-18, 2018.

LATTA, M.; ESKIN, M. A. A simple and rapid colorimetric method for phytate determination. Journal of Agricultural and Food Chemistry, 28: 1313-1315, 1980.

MAPA. Ministério da Agricultura, Pecuária e Abastecimento. Plano nacional para o desenvolvimento da cadeia produtiva do feijão e pulses. Brasília-DF, 2018. 20 p. Disponível em: $<$ http://www.agricultura.gov.br/assuntos/camarassetoriais-tematicas/documentos/camaras-setoriais/ feijao/2018/4a-re/minuta-pndcpfp-indicacaocontribuicoes-versao-02-02-2018.pdf $>$. Acesso em: 04 jan. 2021.

MARTINS, S. M. et al. Genetic parameters and breeding strategies for high levels of iron and zinc in Phaseolus vulgaris L. Genetics and Molecular Research, 15:1-11, 2016.

MAZIERO, S. M.; RIBEIRO, N. D.; FACCO, H. dos S. Genetic parameters of agronomic and nutritional traits of common bean (Phaseolus vulgaris L.) population with biofortified grains. Australian Journal of Crop Science, 10:824-830, 2016.

McCLEAN, P. E. et al. Phenotypic diversity for seed mineral concentration in North American dry bean germplasm of Middle American ancestry. Crop Science, 57: 3129-3144, 2017.

MOJICA, L. et al. Bean cultivars (Phaseolus vulgaris L.) have similar high antioxidant capacity, in vitro inhibition of $\alpha$-amilase and $\alpha$-glucosidase while diverse phenolic composition and concentration. Food Research International, 69: 38 $-48,2015$.

MORAGHAN, J. T.; GRAFTON, K. Distribution of selected elements between the seed coat and embryo of two black bean cultivars. Journal of Plant Nutrition, 25: 169-176, 2002.

OOMAH, B. D.; BLANCHARD, C.; BALASUBRAMANIAN, P. Phytic acid, phytase, minerals, and antioxidant activity in Canadian dry bean (Phaseolus vulgaris L.) cultivars. Journal of Agricultural and Food Chemistry, 56: 1131211319, 2008.

PIRHAYATI, M.; SOLTANIZADEH, N.; KADIVAR, M. Chemical and microstructural evaluation of 'hard-to-cook' phenomenon in legumes (pinto bean and small-type lentil). International Journal of Food Science and Technology, 46: 1884 $-1890,2011$.

PRAVST, I. Risking public health by approving some health claims? - The case of phosphorus. Food Policy, 36: 726-728, 2011.

RAMALHO, M. A. P.; FERREIRA, D. F.; OLIVEIRA, A. C. de. Experimentação em genética e melhoramento de plantas. Lavras, MG: UFLA, 2000. 326 p.

RIBEIRO, N. D.; POSSEBOM, S. B.; STORCK, L. Progresso genético em caracteres agronômicos no melhoramento do feijoeiro. Ciência Rural, 33: 629$633,2003$.

RIBEIRO, N. D. et al. Combined selection for grain yield, cooking quality and minerals in the common bean. Revista Ciência Agronômica, 44: 869-877, 2013.

RIBEIRO, N. D. et al. Desempenho agronômico e qualidade de cozimento de linhagens de feijão de grãos especiais. Revista Ciência Agronômica, 45: 92-100, 2014a. 
RIBEIRO, N. D. et al. Evaluation of special grains bean lines for grain yield, cooking time and mineral concentration. Crop Breeding and Applied Biotechnology, 14: 15-22, 2014 b.

SCHLEMMER, U. et al. Phytate in foods and significance for humans: food sources, intake, processing, bioavailability, protective role and analysis. Molecular Nutritional Food Research, 53: 330-375, 2009.

SILVA, C. A. et al. Chemical composition as related to seed color of common bean. Crop Breeding and Applied Biotechnology, 12: 132-137, 2012.

SINGLETON, V. L.; ROSSI JÚNIOR, A. Colorimetry of total phenolics with phosphomolybdic-phosphotungstic acid reagents. American Journal of Enology and Viticulture, 16: 144-158, 1965.

STECKLING, S. M. et al. Genetic diversity and selection of common bean lines based on technological quality and biofortification. Genetics and Molecular Research, 16: 1-13, 2017.

WIMALAWANSA, S. J.; RAZZAQUE, M. S.; ALDAGHRI, N. M. Calcium and vitamin D in human health: hype or real? Journal of Steroid Biochemistry and Molecular Biology, 180: 4-14, 2018.

WU, X. J., JAMES, R.; ANDERSON, A. K. Mineral contents in seed coat and canning quality of selected cultivars of dark red kidney beans (Phaseolus vulgaris L.). Journal of Food Processing and Preservation, 29: 63-74, 2005.

ZILIO, M.; SOUZA, C. A.; COELHO, C. M. M. Phenotypic diversity of nutrients and anti-nutrients in bean grains grown in different locations. Revista Brasileira de Ciências Agrárias, 12: 528-534, 2017. 